\title{
Expression patterns of cyclin D1 and related proteins regulating G1-S phase transition in uveal melanoma and retinoblastoma
}

\author{
S E Coupland, N Bechrakis, A Schüler, I Anagnostopoulos, M Hummel, N Bornfeld, \\ H Stein
}

\begin{abstract}
Backgroundlaims-A checkpoint mechanism in late $\mathrm{G} 1$, whose regulation via loss of retinoblastoma protein (pRB) or p16, or overexpression of cyclin D1 or cyclin dependent kinase 4 (CDK4), has been proposed to constitute a common pathway to malignancy. The aims of this study were (a) to compare markers of cell cycle G1-S phase transition in an intraocular tumour with known pRB deficiency (retinoblastoma) and compare it with one with an apparently functional pRB (uveal melanoma); (b) to determine if one of these markers may have a role in the pathogenesis of uveal melanoma; and (c) to determine if there is a difference in cell cycle marker expression following treatment of uveal melanoma and retinoblastoma.
\end{abstract}

Methods-90 eyes were enucleated from 89 patients for retinoblastoma $(n=24)$ or for choroidal or ciliary body melanoma $(n=66)$. Conventional paraffin sections were assessed for cell type and degree of differentiation. Additional slides were investigated applying standard immunohistochemical methods with antibodies specific for cyclin D1 protein, pRB, p53, p21, p16, BCL-2, and MIB-1.

Results-Cyclin D1 protein and $\mathrm{pRB}$ were negative in retinoblastoma using the applied antibodies. In contrast, cyclin D1 protein expression was observed in $65 \%$ of uveal melanomas; a positive correlation between cyclin D1 cell positivity and tumour cell type, location, growth fraction, as well as with $\mathrm{pRB}$ positivity was observed. p53, p21, and p16 could be demonstrated in both tumours. An inverse relation between p53 and p21 expression was demonstrated in most choroidal melanomas and in some retinoblastomas. Apart from a decrease in the growth fractions of the tumours as determined by MIB-1, a significant difference in the expression of G1-S phase transition markers in vital areas of uveal melanoma and retinoblastoma following treatment with radiotherapy and/or chemotherapy was not observed.

Conclusion-Retinoblastomas and uveal melanomas, two tumours of differing pRB status, differ also in their immunohistochemical pattern for markers of the G1-S phase transition of the cell cycle. The results of the present study support the concept of (a) an autoregulatory loop between pRB and cyclin D1 in tumours with a functional $\mathrm{pRB}$ and the disruption of this loop in the presence of $\mathrm{pRB}$ mutation, as well as (b) a checkpoint mechanism in late $G 1$, whose regulation via loss of p16 or $\mathrm{pRB}$, or overexpression of cyclin D1 constitutes a common pathway to malignancy. Further, the results raise the possibility of cyclin D1 overexpression having a role in the pathogenesis of uveal melanoma.

(Br f Ophthalmol 1998;82:961-970)

Cyclins are cell cycle regulatory molecules which complex with and activate cyclin dependent kinases (CDKs) to govern cell cycle progression (Fig 1) (Table 1). ${ }^{1}$ They include cyclin D1 protein which binds with CDK4, leading to phosphorylation of the retinoblastoma protein $(\mathrm{pRB})$, a product of the tumour suppressor gene located on chromosome 13 q14 which can inhibit cell proliferation (Fig 1). Phosphorylation of $\mathrm{pRB}$ results in a change in $\mathrm{pRB}$ molecule configuration, the release of transcription factors bound to $\mathrm{pRB}$, such as E2F, and ultimate cell cycle progression from G1 to the $S$ phase (Fig 1). ${ }^{2}{ }^{3}$ Interest in a possible role of cyclin D1 in tumorigenesis has grown since experiments demonstrated that induction of cyclin D1 in cells arrested in the early G1 phase by transfection with $\mathrm{pRB}$ was sufficient for cell cycle completion. ${ }^{4}$ Further, cyclin D1 overexpression has been reported in several tumours including parathyroid adenomas, ${ }^{5}$ mantle cell lymphoma, ${ }^{67}$ malignant melanoma of the skin, ${ }^{8}$ as well as carcinomas of the breast, lung, liver, oesophagus, urinary bladder, head and neck, vulva, and uterine cervix. ${ }^{8-14}$

In addition to cyclin D1, other cell cycle regulatory molecules may participate in the development and progression of human tumours. In particular, a group of cyclin dependent kinase inhibitors (CDKIs) have been proposed in tumorigenesis as possible tumour suppressor genes ${ }^{15-17}$ (Fig 1) (Table 1). These proteins act as negative regulatory elements of cell proliferation by inhibiting the kinase activity of the cyclin/CDK complexes and are, thereby, implicated in the mechanisms of cell arrest that allow the cell time for DNA repair. Of these molecules, p16 and p21 are strong candidates to participate in tumour progression. p16 gene (CDKN2/MTS1/ INK $^{4 a}$ ) is located on chromosome $9 \mathrm{p} 21$ and has been found to be deleted, mutated, or 
downregulated by hypermethylation at high frequency in different types of tumours, including cutaneous and uveal melanomas. ${ }^{15}$ 17-20 Experimental evidence has confirmed p16 as an anti-oncogene and the incidence of its mutations appears to be inversely correlated with frequencies of other oncogenic mutations, such as the loss of $\mathrm{pRB}$, along the cyclin D1/CDK/p16/pRB pathway. ${ }^{2}$

p21 gene (WAF1/Cip1/SDI1), located on chromosome 6 , results in G1 arrest via the inhibition of the CDKs and via an interaction with the proliferating cell nuclear antigen protein. ${ }^{22}$ Although it can be activated via $\mathrm{p} 53$ independent mechanisms, ${ }^{23}$ p21 is induced by "wild type" but not mutant tumour suppressor gene p53. It is, therefore, considered to be a critical downstream effector of p53 in cell cycle arrest. ${ }^{22} 2425$ In normal tissues, p21 has been associated with maintaining growth arrest in terminally differentiated tissues. ${ }^{26}$ Somatic mutations in p21 gene are rare in human tumours $^{27}$; however, some have been demonstrated in human prostate cancer. ${ }^{28}$

Apart from inducing cell arrest, the tumour suppressor gene p53, located on chromosome $17 \mathrm{q}$, has a second distinctive function depending on the cell type. This second function is the induction of apoptosis, also known as programmed cell death (PCD).$^{29}$ Wild type p53 has been associated with a downregulation in the anti-apoptotic gene $b c l-2$ and an upregulation in the $b c l-2$ associated gene bax, this combination resulting in apoptosis induction. Disruption of this balance can occur owing to a loss of normal p53 gene function or to a dysregulation of BCL-2 protein expressionfor example, following the characteristic $t(14 ; 18)$ translocation observed in follicular lymphoma. ${ }^{30}$ Thereby, the balance is tipped towards the prevention of PCD, a characteristic of $b c l-2$ which distinguishes it from other oncogenes, which promote cell proliferation as their mechanism of tumorigenesis. An inverse relation between BCL-2 protein expression and mutant p53 expression has been shown in malignant lymphoma, ${ }^{31}$ breast $^{32}{ }^{33}$ and thyroid carcinoma. ${ }^{34}$

Retinoblastoma is the most common intraocular tumour in childhood occurring in one of 17000 to 24000 live births, ${ }^{35-38}$ and it may occur either as a hereditary or a sporadic tumour. The chromosome locus of the retinoblastoma gene is in the region $13 \mathrm{q} 14$ and according to the "two hit hypothesis" proposed by Knudson, ${ }^{39}$ two mutational events leading to the inactivation or deletion of both alleles of the retinoblastoma locus must occur before the development of retinoblastoma. Uveal melanoma, on the other hand, is the most frequent primary intraocular tumour in white adults with an incidence of 0.7 per $100000 .{ }^{40}$ The pathogenesis of uveal melanoma is unclear and probably represents a multistep process involving the progressive and clonal accumulation of multiple genetic lesions affecting protooncogenes and tumour suppressor genes. Recent studies have demonstrated certain genetic changes associated with these tumours, in particular, monosomy 3, multiplication of chromosome $8 \mathrm{q}$, as well as loss of $9 \mathrm{p}^{41-47}$

Although the role of RB gene has been clarified in retinoblastoma, ${ }^{39}$ little is known about the cell cycle markers of G1-S phase transition and their relation to each other in this tumour. Further, only occasional reports have addressed these issues in uveal melanoma. ${ }^{19}$ In the present study, we investigated the expression of cyclin D1 in one type of intraocular tumour where mutations of the $\mathrm{pRB}$ are present (retinoblastoma) and compared it with another with an apparently functional $\mathrm{pRB}$ (uveal melanoma). In particular, we investigated the relation between cyclin $\mathrm{D} 1$ protein expression and that of $\mathrm{pRB}, \mathrm{p} 53, \mathrm{p} 21$, and $\mathrm{p} 16$ in these two tumours. We also analysed whether there was a possible correlation between expression of these cell cycle markers

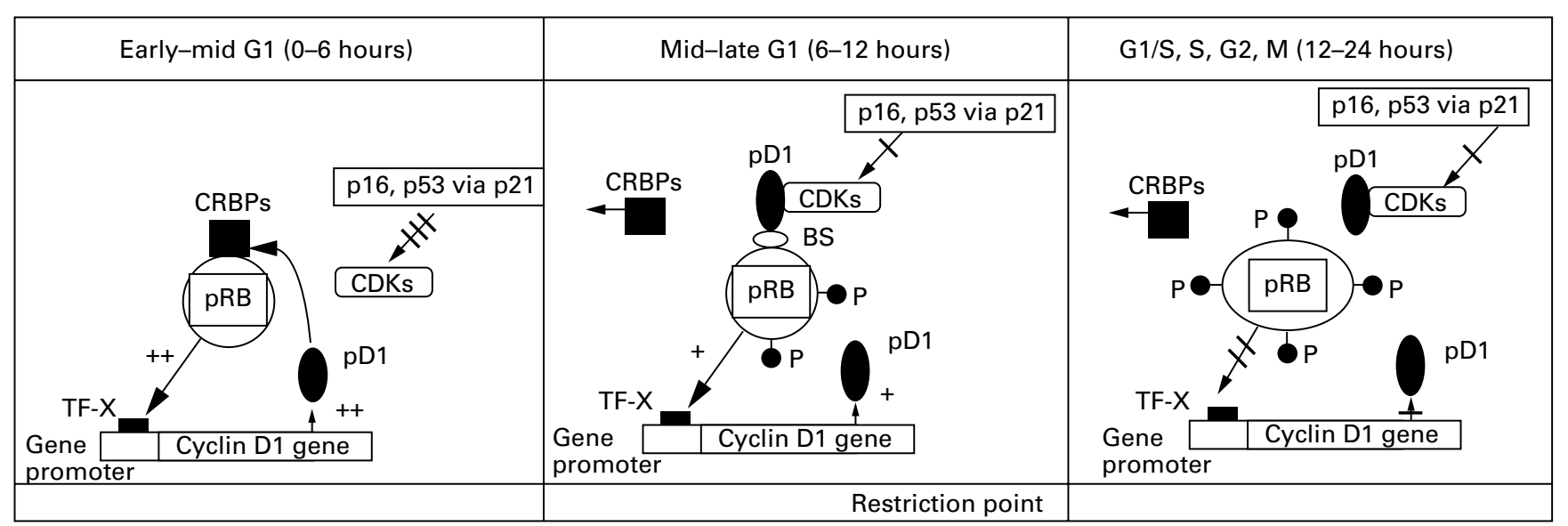

Figure 1 Interactions between cyclin D1 gene and protein ( $p D 1)$ and retinoblastoma protein ( $p R B$ ) as well as between the cyclin dependent kinases $(C D K s)$ and their inhibitors ( 16 and 21 via $p 53$ ) during the cell cycle (modified from Lukas et al ${ }^{55}$ ). During early to mid G1, the concentrations of pD1 are low. pRB is hypophosphorylated and has a stimulatory activity on the transcription of the cyclin D1 gene. At this time, the retinoblastoma "pockets" are occupied by "cellular retinoblastoma binding proteins" (CRBPs), which are potent cell cycle stimulators when released later from the pRB pockets. The $C D K s$ are inhibited by the CDKIs, including $p 16$ and $p 21$, the latter being stimulated by $p 53$. The combination of hypophosphorylated $p R B$, the $p R B$ bound CRBPs, and the inhibitory effects of the CDKIs contribute to cell cycle arrest at the restriction point (R point) in the mid to late G1 phase. The concentrations of pD1 increase and eventually are sufficient to combine with the CDKs, overriding the inhibitory activity of the CDKIs and resulting in (a) the displacement of the CRBPs from the RB pockets, (b) phosphorylation of the $p R B$, causing a change in the configuration of the pRB molecule. These alterations stimulate cell progression into the $S$ phase, as well as a decrease in the transcriptional stimulus of the cyclin D1 gene. The concentration of pD1, consequentially, decreases during the $S, G 2$, and $M$ phases. TF-X represents a proposed transcription factor ${ }^{55}$ and BS, a possible binding site or molecule through which cyclin D1 indirectly interacts with $p R B$. 
Table 1 Molecules involved in executing cell cycle arrest at the restriction point ( $R$ point) between $G 1-S$ phase $(A)$ and those involved in recommencement of cell cycling after the $R$ point $(B)$

\begin{tabular}{ll}
\hline$A$ & $B$ \\
\hline $\begin{array}{l}\text { CDKIs: p53 via p21; p16 } \\
\text { hypophosphorylated pRB }\end{array}$ & $\begin{array}{l}\text { Cyclin D1 } \\
\text { CDKs } \\
\text { hyperphosphorylated pRB } \\
\text { CRBPs (for example, E2F) }\end{array}$ \\
\hline
\end{tabular}

of G1-S phase transition and the growth fraction of the tumour, as determined by the Ki-67 antigen, or with BCL-2 expression.

\section{Methods}

CONVENTIONAL HISTOLOGY AND

IMMUNOHISTOLOGY

Ninety eyes were enucleated for either uveal melanoma $(n=66)$ or retinoblastoma $(n=24)$. Eight eyes donated for corneal transplantation with an average postmortem time of 12 hours served as controls. All enucleated eyes were fixed in $10 \%$ buffered formalin and embedded in paraffin wax. Conventional histological stains of the uveal melanomas were assessed for cell type using the modified Callender system $^{48}$ - that is, spindle A, spindle B, epithelioid, and mixed cell type. Retinoblastomas were graded as to the degree of differentiation according to a system proposed by Nork and coworkers. ${ }^{49}$ Briefly, the grades of differentiated were: (1) poorly differentiated-cells with high nuclear to cytoplasmic ratios with a high mitotic index. Pseudorosettes and HomerWright rosettes were found in such areas; (2) moderately differentiated-cells with moderate nuclear to cytoplasmic ratios, a moderate mitotic index, and possible pseudorosettes and Flexner-Winterstein rosettes; (3) well differentiated-cells with a low nuclear to cytoplasmic ratio, a low mitotic index, and the formation of florets. The recently described "zones 1, 2, and 3" around pseudorosettes ${ }^{49}$ were used for the evaluation of tumour cell staining. Briefly, these were as follows "zone 1" (central region near blood vessel), "zone 2 " (adjacent to edge of the pseudorosette), and "zone 3" (edge of pseudorosette). ${ }^{49}$

Additional slides were stained for immunohistochemical studies using several monoclonal and polyclonal antibodies that are reactive in paraffin embedded tissues. An antigen retrieval method using a pressure cooker was performed before immunohistochemical staining. ${ }^{50}$ The staining consisted of a first stage incubation with the following primary monoclonal antibodies: cyclin D1 (clone P2D11F11; Novocastra; Germany); retinoblastoma protein ( $\mathrm{pRB}$ ) (clone G3-245 which binds to an epitope between amino acids 300-380 of human RB; Pharmingen; Germany); p53 (clone DO7 which recognises both wild type and mutant p53 proteins; Dako; Denmark); p21 (clone DCS-60.2; Neomarkers; Germany); p16 (clone DCS-50.1/A7; Neomarkers; Germany); BCL-2 (clone 124; Dako; Denmark); MIB-1 (antigen $\mathrm{Ki}-67$ which reacts with a DNA associated antigen in the nuclei at all phases of the cell cycle except the resting phase ${ }^{51}$; the antibody was kindly provided by Dr J Gerdes,
Borstel, Germany); and glial fibrillary acid protein (clone 6F2; GFAP; Dako; Denmark). The antibodies were made visible with an indirect immunoperoxidase method for p53, whereas the alkaline phosphatase anti-alkaline phosphatase (APAAP) method was used to demonstrate the binding of the remaining antibodies. ${ }^{52}$ In heavily pigmented tumours, the sections were placed in hydrogen peroxide for 18 hours to remove melanin pigmentation from the tumour cells before cover slipping the slides, as previously described..$^{53}$

Cells were considered positive for cyclin D1, pRB, p53, p16, p21, and for MIB-1 only when distinct nuclear staining was identified. The percentage of immunoreactive nuclei in the uveal melanoma and retinoblastoma was evaluated by counting at least $5 \times 100$ cells using the $40 \times$ objective (Olympus, $\mathrm{BH} 2$ ). Positive controls included cases of mantle cell lymphoma for cyclin D1, colon carcinoma for p21, and gastric and breast carcinoma for p16. Negative controls were obtained by omitting the primary monoclonal antibodies.

STATISTICAL ANALYSIS

Comparison of differences was performed using the Student's $t$ test. $\mathrm{p}$ Values at less than 0.05 were interpreted to be statistically significant.

\section{Results}

CLINICAL FEATURES

The patients $(n=23)$ with retinoblastoma consisted of eight females and 15 males with an age range of 4 months to 19 years; mean 3 years. Twelve patients had bilateral tumours and 11 unilateral. Sixteen patients were treated with primary enucleation; five with chemoreduction before planned enucleation; two with combined chemotherapy and radiotherapy before enucleation; and one patient with radiotherapy alone.

The patients $(n=66)$ with uveal melanoma consisted of 39 females and 27 males with an age range of 9-88 years; mean 59 years. Fifty five patients had been treated with primary enucleation or local excision of the tumour; nine with radiotherapy before enucleation.

CONVENTIONAL AND IMMUNOHISTOLOGY

The results of the immunohistochemical investigations are summarised in Table 2.

\section{Normal choroid and retina}

Cyclin D1 was observed in occasional ganglion cells of the normal retina (Fig 2a); a similar staining pattern was observed for p53 (Fig 2b) and $\mathrm{p} 16$. Positive staining for $\mathrm{pRB}$ and $\mathrm{p} 21$ (Fig 2c) was observed in all cell layers of the normal retina. BCL-2 positivity was observed in scattered ganglion cells, the bipolar cells, and in perivascular astrocytes (Table 2) (Fig $2 \mathrm{~d})$.

The choroidal melanocytes were negative for cyclin D1, pRB, p53, and p16. Occasional melanocytes, as well as scattered reactive $T$ and B lymphocytes, were positive for $\mathrm{p} 21$ and BCL-2 (Fig 2e) (Table 2). 
Retinoblastoma

Cyclin D1 positive cells were rarely seen in retinoblastoma and when present corresponded to glial cells (Fig 3a), also positive for GFAP. Similarly, retinoblastoma cells were negative for
pRB using the applied antibody, staining for pRB being observed only in vascular endothelial cells and some perivascular GFAP positive glial cells (Table 2). Excluding those retinoblastomas which had been treated with chemo-

Table 2 Summary of the immunohistochemical findings for cyclin D1 and related G1-S phase proteins in the normal retina, untreated retinoblastoma, and untreated choroidal melanoma

\begin{tabular}{lllll}
\hline & Normal retina & Retinoblastoma & Normal choroid & Choroidal melanoma \\
\hline Cyclin D1 & GCL positive & negative & negative & positive $(2-75 \%)^{\star}$ \\
pRB & all layers positive & negative & negative & positive $(5-65 \%)$ \\
p53 & GCL positive & PDA $>$ MDA $>$ WDA & negative & positive $(2-30 \%)$ \\
p21 & all layers positive & PDA and MDA & lymphocytes only & positive $(5-30 \%)$ \\
p16 & GCL positive & PDA and MDA & negative & positive $(5-25 \%)$ \\
BCL-2 & GCL, BC and PA positive & GC & lymphocytes only & positive $(100 \%)$ \\
MIB-1 & NA & PDA (80\%) & NA & $5-50 \%$ \\
& & MDA (30\%) & & \\
& & WDA $(5 \%)$ & &
\end{tabular}

$\mathrm{pRB}=$ retinoblastoma protein $; \mathrm{GCL}=$ ganglion cell layer; $\mathrm{BC}=$ bipolar cells; $\mathrm{PA}=$ perivascular astrocytes; $\mathrm{GC}=$ glial cells; PDA = poorly differentiated area $\mathrm{MDA}=$ moderately differentiated area; $\mathrm{WDA}=$ well differentiated area. $\mathrm{NA}=$ not applicable

$\star$ Percentages in parentheses represent the number of tumour cells per 100 positive for the various markers.
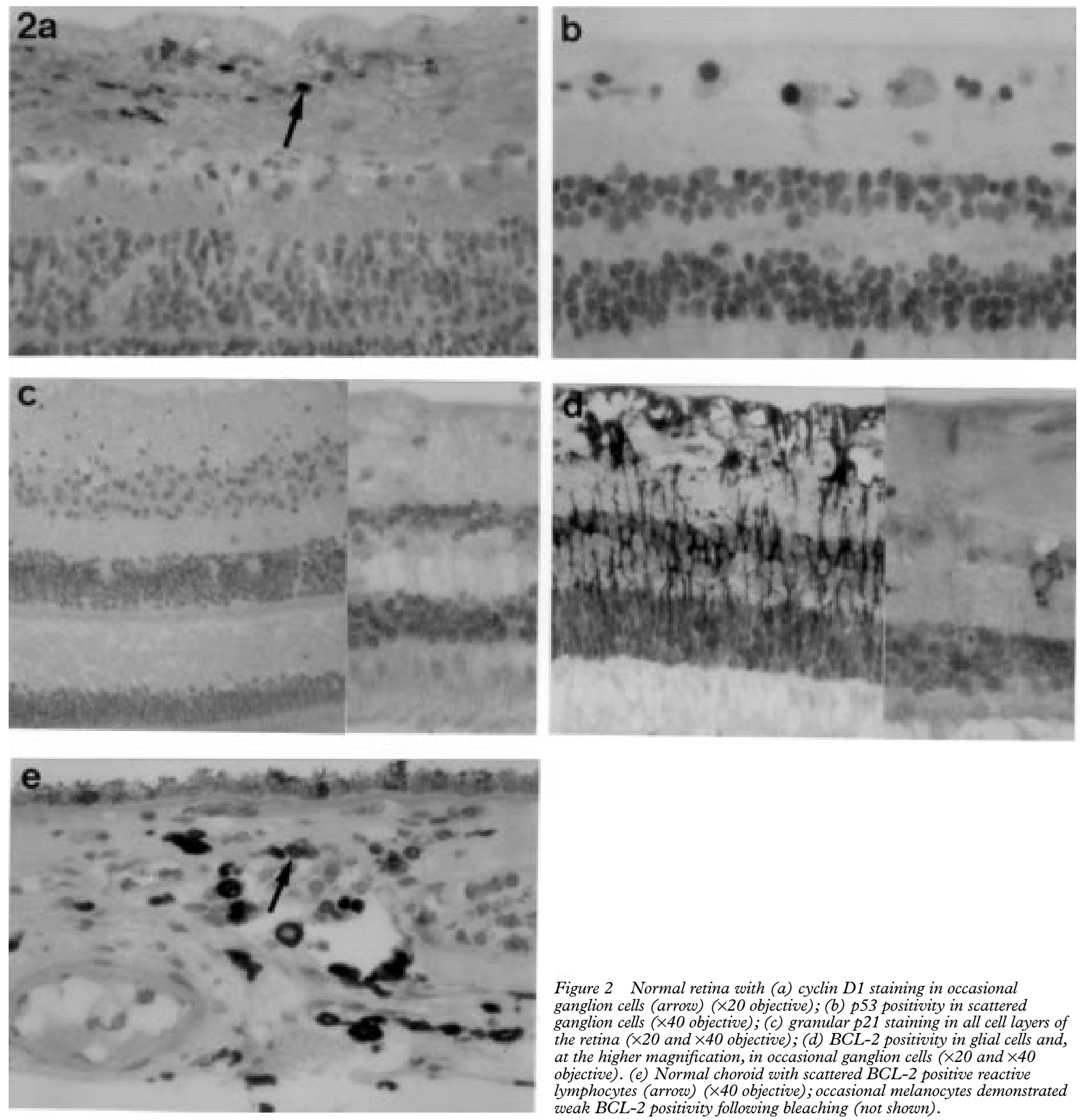

Figure 2 Normal retina with (a) cyclin D1 staining in occasional ganglion cells (arrow) ( $\times 20$ objective); (b) p53 positivity in scattered ganglion cells ( $\times 40$ objective); (c) granular $p 21$ staining in all cell layers of the retina $(\times 20$ and $\times 40$ objective); (d) BCL-2 positivity in glial cells and, at the higher magnification, in occasional ganglion cells $(\times 20$ and $\times 40$ objective). (e) Normal choroid with scattered BCL-2 positive reactive lymphocytes (arrow) ( $\times 40$ objective); occasional melanocytes demonstrated weak BCL-2 positivity following bleaching (not shown). 

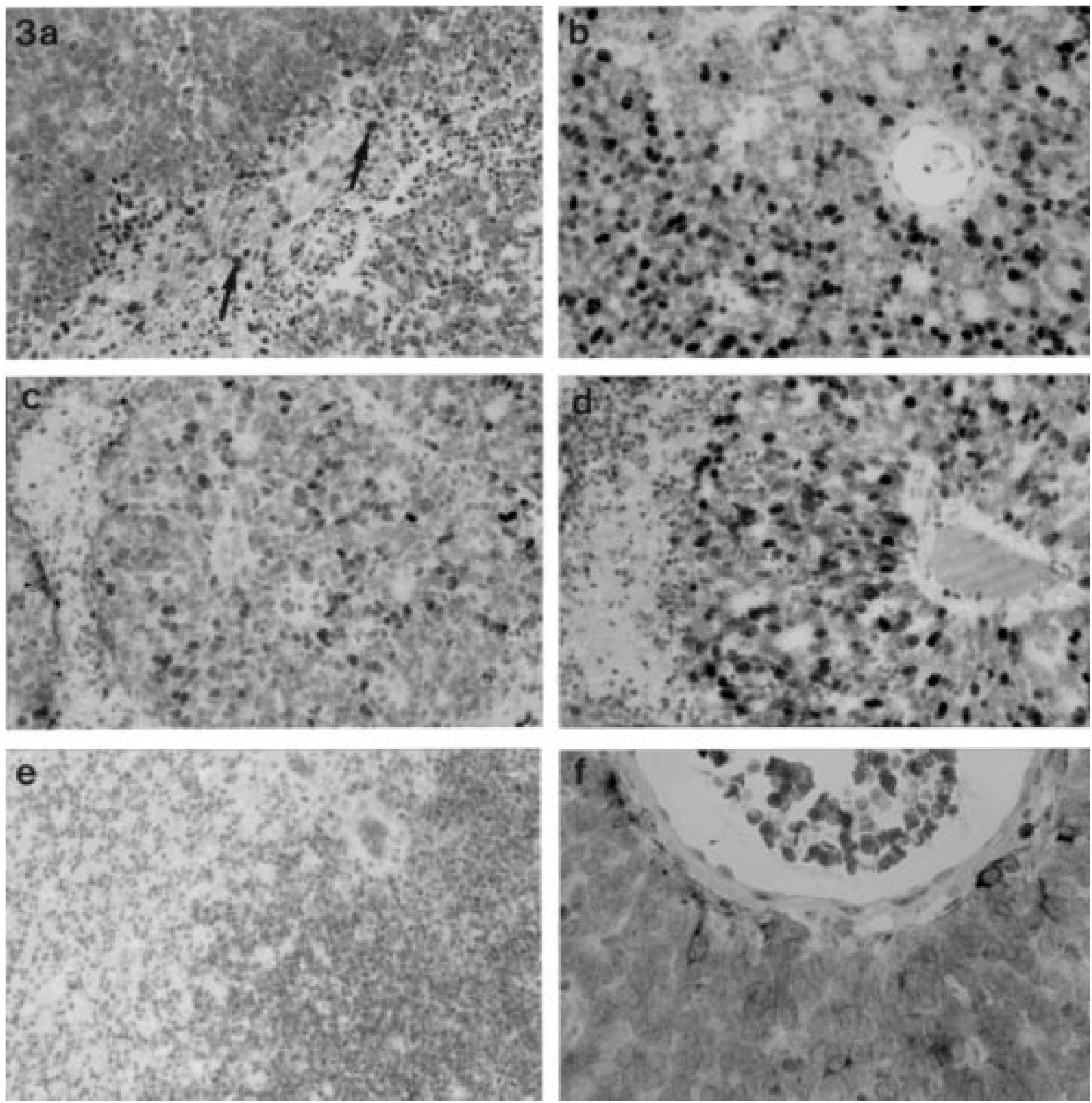

Figure 3 (a) Cyclin D1 positivity in reactive glial cells (arrow) within retinoblastoma; the tumour cells are negative $(\times 20$ objective). (b) The degree of differentiation within the retinoblastomas is reflected by the corresponding MIB-1 growth fractions ( $\times 20$ objective); (c) p53; and (d) p21 positivity

surrounding a pseudorosette where staining of these markers is present in all "zones" ( $\times 40$ objective); (e) p16 staining in poorly and moderately

differentiated tumours areas within a retinoblastoma $(\times 20$ objective). $(f)$ Perivascular glial cells positive for BCL-2 in a retinoblastoma; the tumour cells are negative ( $\times 40$ objective).

therapy, radiation, or with a combination of the two before enucleation, most retinoblastomas demonstrated all three grades of cell differentiation. These were reflected to some extent by the growth fraction of the tumour cells as well as by the percentages of cells positive for the p53, $\mathrm{p} 21$, and $\mathrm{p} 16$. The highest proliferating cell populations were observed in the poorly differentiated areas with growth fractions of $60-90 \%$ (mean $80 \%$ ). In the moderately and well differentiated areas, the growth fractions were significantly lower, averaging $30 \%$ and $5 \%$, respectively (Fig 3b). Highest percentages of p53 positive cells (mean $60 \%$ ) were observed in the poorly differentiated areas; lower percentages (mean $25 \%$ ) in the moderately differenti- ated areas within the Flexner-Winterstein rosettes; and only scattered p53 positive cells were observed in the well differentiated areas. p21 positive tumour cells were observed in the poorly and moderately differentiated areas; occasional cells were positive for p21 in the well differentiated tumour areas (Table 2). The recently described zonal differentiation of p53 and $\mathrm{p} 21$ staining cells in pseudorosettes- $\mathrm{p} 21$ adjacent to the central blood vessel (zone 1) and p53 adjacent to the pseudorosette edge (zone 2$)^{49}$-was observed in many retinoblastomas. A large proportion of pseudorosettes, however, demonstrated p53 and p21 positive cells in both zones (Fig $3 \mathrm{c}$ and d, respectively). p16 stained positively in high percentages in 

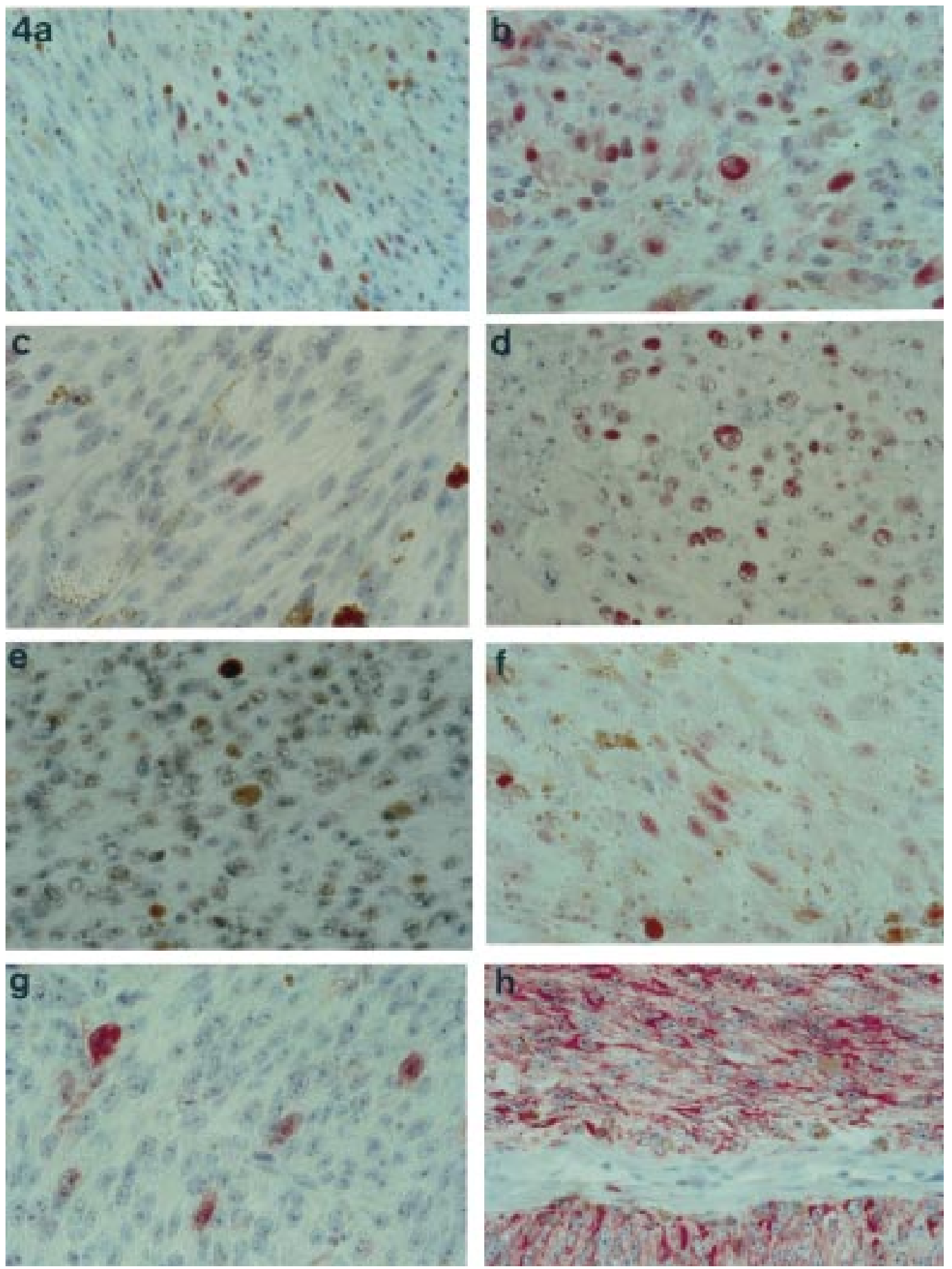

Figure 4 Cyclin D1 positivity in a spindle (a) and epithelioid (b) choroidal melanoma $(\times 20$ objective). pRB positivity in a spindle (c) and epithelioid (d) choroidal melanoma ( $\times 20$ objective). (e) Clear $p 53$ positivity in choroidal melanoma (arrow) ( $\times 20$ objective). $(f)$ p21 staining in occasional tumour cells of a mixed cell choroidal melanoma $(\times 20$ objective). (g) p16 positivity in scattered tumour cells of a mixed cell choroidal melanoma ( $\times 40$ objective). (h) BCL-2 staining in a spindle choroidal melanoma ( $\times 20$ objective).

areas of poor and moderate differentiation (Fig $3 \mathrm{e})$. Cells in zones 1 and 2 of the pseudorosettes were positive for $\mathrm{p} 16$. Only rare $\mathrm{p} 16$ positive cells were observed in well differentiated tumour areas.

Perivascular glial cells in areas of all grades of cellular differentiation were positive for BCL-2 (Fig 3f). Further, scattered or occasional groups of glial cells positive for BCL-2 were present between the tumour cells.

The nine retinoblastomas from patients treated with chemotherapy, chemoreduction, or radiation before enucleation demonstrated extensive calcification of the devitalised neo-

plastic cells, cystic degeneration, as well as reactive gliosis. Changes to retinoblastoma following treatment as well as those observed in adjacent ocular tissue have been described in more detail elsewhere. ${ }^{54}$ Three tumours demonstrated vital tumour with growth fractions of $10 \%$ in one case and $90 \%$ in the other two. Occasional vital retinoblastoma cells were positive for $\mathrm{p} 53, \mathrm{p} 21$, and $\mathrm{p} 16$; there was no alteration in the expression of these markers compared with the "untreated" tumours in the vital areas of the tumour. All post-treatment retinoblastomas were negative for cyclin D1, $\mathrm{pRB}$, and BCL-2. 
A correlation between the above G1-S cell cycle markers and the laterality of the tumours was not demonstrated.

\section{Uveal melanomas}

Forty five of the uveal melanomas arose from the choroid; 18 from the ciliary body; and one in the iris. Of the choroidal melanomas, 37 were posterior to, or close to the equator; eight tumours were anterior to this with no infiltration of the pars plana of the ciliary body. The uveal melanomas consisted of 21 spindle B, 29 mixed tumours with spindle B predominance, seven pure epithelioid tumours, and seven mixed tumours with epithelioid predominance. Extraocular extension of tumour was observed in nine cases.

Excluding those uveal melanoma which had been treated with radiotherapy before enucleation, nuclear positivity of cyclin D1 was observed in $85 \%$ of cases with the percentage of positive cells ranging between $2 \%$ and $75 \%$ (Table 2). The cyclin D1 percentage expression correlated positively with the growth fraction of the tumours which varied between $5 \%$ and $55 \% \quad(\mathrm{p}<0.05$, Student's $t$ test $)$. The percentage of cells positive for MIB-1 and cyclin D1 significantly correlated with cell type: pure or mixed epithelioid tumours demonstrated a greater percentage of MIB-1 and cyclin D1 positive cells than spindle cell tumours ( $p<0.05$, respectively) (Fig $4 \mathrm{a}$ and $\mathrm{b})$. Further, the percentage of cyclin D1 positive cells was greater in the anteriorly located tumours or those which showed extraocular tumour extension $(\mathrm{p}<0.05)$.

$\mathrm{pRB}$ tumour cell positivity varied between $5 \%$ and $65 \%$ (Table 2 ) and a significant correlation was observed between the percentage of cells expressing $\mathrm{pRB}$ and the MIB-1 growth fraction of the tumour $(\mathrm{p}<0.05)$. Further, a positive correlation existed between $\mathrm{pRB}$ and the cyclin D1 expression, the cell type (less in spindle cell tumours) (Fig $4 \mathrm{c}$ and d) and anatomical location of the tumour (higher percentage in the anteriorly located tumours) ( $p<0.05$, respectively).

p53 expression was found in $60 \%$ of cases, with the percentage of positive cells varying between $2 \%$ and $30 \%$ (Fig 4e) (Table 2). Higher percentages of $\mathrm{p} 53$ positivity tended to occur in epithelioid cells; however, this was not statistically significant $(p=0.09)$. Further, statistically significant correlations between p53 expression and the MIB-1 growth fraction, cyclin D1 and pRB positivity, and the tumour location were not observed.

Occasional tumour cells were positive for p 21 in most cases $(65 \%)$, range $5-30 \%$ (mean $8 \%$ ) (Fig 4f). A statistically significant inverse relation between p53 and p21 was observed with a decreased p21 expression in tumours with high percentage $\mathrm{p} 53$ expression $(\mathrm{p}<0.05)$. Double staining demonstrated that p53 and p21 positive cells were distinct from one another (not shown). A significant correlation between p21 positive cells and the MIB-1 growth fraction, cyclin D1 and pRB positivity, tumour cell type or tumour location was not observed.
Immunohistochemical detection with p16 showed both nuclear and cytoplasmic staining in uveal melanoma; p16 cells were the scattered cells seen in $45 \%$ of cases and this positivity varied between $5 \%$ and $25 \%$ (mean $12 \%$ ) of tumour cells (Table 2) (Fig 4g). There was no correlation with cell type, tumour location, or the percentage of cells positive for $\mathrm{pRB}$. Double staining demonstrated exclusive staining for $\mathrm{p} 16$ and $\mathrm{pRB}$ in uveal melanoma.

All uveal melanomas stained for BCL-2, with no variation being observed between tumour location, tumour cell type (Fig 4h), MIB-1 growth fraction, cyclin D1, pRB, p53, p21, or p16 positivity. Despite bleaching procedures, slight variations in the intensity of the BCL-2 staining occurred in heavily pigmented tumours owing to the cytoplasmic location of the BCL-2 protein.

The nine uveal melanomas which had been treated with radiotherapy before enucleation demonstrated necrosis as well as a massive infiltration of melanomacrophages. The growth fraction of these tumours was significantly lower in comparison with untreated tumours, varying between $1 \%$ and $5 \%$, mean $3 \%(\mathrm{p}<0.05)$. Vital melanoma cells were positive for BCL-2 and, occasionally, for cyclin D1, $\mathrm{pRB}, \mathrm{p} 53, \mathrm{p} 21$, and $\mathrm{p} 16$. There was no change in expression of these markers in the vital tumour areas compared with the "untreated" tumours.

\section{Discussion}

The present study represents the first immunohistochemical investigation and description of cyclin D1 protein expression in retinoblastoma and uveal melanoma. The two tumours were chosen for their differing retinoblastoma gene status in order to investigate the expression of cyclin D1 and related G1-S transition proteins dependent on pRB status. Recent studies on cell lines and data from in vitro systems have provided evidence for an autoregulatory loop between cyclin D1 and pRB in normal cells and tumour cells with a functional $\mathrm{pRB}$ (Fig 1). ${ }^{55}$ According to this model, transcription of cyclin D1 gene is stimulated by hypophosphorylated $\mathrm{pRB}$ in the early stages of $\mathrm{G} 1$ and is later repressed by its hyperphosphorylated form (Fig 1). Disruption of this loop has been proposed to occur in three ways. The first is the binding of DNA viruses to the $\mathrm{pRB}$ binding "pockets" 55 and will not be further addressed here. The second is the mutation of the $\mathrm{pRB}$ molecule, which predominantly involves the $\mathrm{pRB}$ binding pockets. ${ }^{55}$ In human tumours with mutations in both alleles of the $\mathrm{RB}$ gene, functional $\mathrm{pRB}$ is absent and can no longer regulate transcriptional factors such as E2F. E2F is, thereby, freed from the $\mathrm{pRB}$ binding pockets and from the inhibitory regulation of $\mathrm{pRB}$ at inappropriate times and, consequently, cell proliferation is stimulated. Further, there is a decrease in the transcriptional stimulus of cyclin D1 by the mutated pRB. ${ }^{55}$ The third mechanism, by which the autoregulatory loop between pRB and cyclin D1 can be disrupted, is the overexpression of cyclin D1 by gene amplification, resulting in accelerated 
phosphorylation of $\mathrm{pRB}$ and the inactivation of its inhibitory effect on cell cycle progression. ${ }^{55}$ The exact mechanism by which cyclin D1 overexpression has its oncogenic effect is unclear. Two mechanisms have been proposed-by directly binding to $\mathrm{pRB}$ or by reducing the levels $\mathrm{pRB}$ in the cell. ${ }^{24}$ Both mechanisms have been recently questioned in studies on low grade B cell lymphomas.

In the current study, retinoblastoma tumour cells were negative for cyclin D1 and pRB using the antibodies applied. Uveal melanoma cells, in contrast, demonstrated positivity for both cyclin D1 and $\mathrm{pRB}$ in varying percentages, with a positive correlation existing between these two markers $(p<0.05)$, as well as with the growth fraction of the choroidal melanoma $(p<0.05)$. Our data are in agreement with those of previous studies investigating tissue sections for $\mathrm{pRB}^{56}{ }^{57}$ and cell lines for cyclin D $1 .^{55}$ The absence of $\mathrm{pRB}$ and cyclin D1 protein staining in retinoblastoma cells may be explained by the above mentioned second mechanism leading to disruption of the autoregulatory loop between cyclin D1 and pRB. The cause of cyclin D1 overexpression in the uveal melanomas - for example, via a heterogeneous cyclin D1 gene promoter or via gene translocation, as in the case of mantle cell lymphoma, must be investigated further. The positive relation between cyclin $\mathrm{D} 1$ and $\mathrm{pRB}$ observed in choroidal melanoma, however, would tend to support the suggestion of Zukerberg and colleagues that cyclin D1 does not exerts its tumorigenic effect by $\mathrm{pRB}$ level reduction. ${ }^{7}$

Strong expression of $\mathrm{p} 16$, a protein which acts as a kinase inhibitor of the cyclin/CDK complexes, was observed in retinoblastoma in areas of moderate and poor differentiation. It was also demonstrated in $\mathrm{pRB}$ negative cells in $45 \%$ of uveal melanomas. The variable expression of $\mathrm{p} 16$ observed in uveal melanomas in the current study parallels to some extent the findings of Ohta et al who reported chromosomal abnormalities involving the p16 gene in $32 \%$ of cases examined. ${ }^{19}$ In general, the results of $\mathrm{p} 16$ expression in both tumour types are consistent with studies which have demonstrated high levels of p16 expression in cell lines with lack of $\mathrm{pRB}$ function $^{58}$ and would support the proposal of a negative feedback system between the two proteins. ${ }^{59}{ }^{60}$ Further, they are in agreement with the results of immunohistochemical investigations of other tumours where a reciprocal expression of $\mathrm{p} 16$ and $\mathrm{pRB}$ was demonstrated. ${ }^{6162}$ These current models do not explain, however, the absence of p16 expression in well differentiated areas of retinoblastomas (also negative for $\mathrm{pRB}$ ). Together with biochemical analysis further investigations are presently being conducted with newer p16 antibodies, in order to underline the significance of the present findings.

Some variation exists between the previously reported investigations of p53 expression in uveal melanoma ${ }^{636}$ and can most likely be accounted for by the differing fixation techniques, the differing p53 antibodies, as well as differing antigen retrieval techniques used.
Such problems with p53 immunohistochemical investigations have been recently addressed in other human cancers in detail and the value of the immunohistochemical analysis alone as being indicative of mutations in the p53 gene has been questioned..$^{65}$ In the current study, the majority $(60 \%)$ of uveal melanomas demonstrated p53 positivity with cell percentages varying between $2 \%$ and $30 \%$. Previous authors have reported $54 \%{ }^{63}$ and $67 \%{ }^{64}$ of cases of uveal melanomas being positive for p53. Details regarding the percentage of tumour cells positive for this marker were not given in the latter study. One group of investigators defined p53 overexpression as being greater than $10 \%$ and this was only observed in five patients, all of whom had been treated with preoperative telecobalt or ruthenium irradiation before enucleation. ${ }^{63}$ Although our results do not support such an association between p53 expression and irradiation, we agree with these authors' observation that p53 positivity tended to be greater in epithelioid tumours.

The critical downstream effector of $\mathrm{p} 53$ specific pathway growth control, p21, was observed in both intraocular tumours in the current investigation. Further, the inverse relation between p53 and p21 protein expression described in normal tissue and in other tumours, ${ }^{26}$ could be demonstrated in some pseudorosettes within the retinoblastomas and in uveal melanomas. Nork and coworkers have recently proposed a zonal arrangement of p53 and $\mathrm{p} 21$ positive cells in tumour areas adjacent to pseudorosettes in retinoblastoma. ${ }^{49}$ The authors reported that zone 1, 2, and 3 cells surrounding the pseudorosettes have the highest staining of cells for p21, p53, and transferase mediated biotin dUTP nick end labelling, respectively and that an overexpression of p53 in zone 2 leads to the ultimate onset of apoptosis observed at the edge of the pseudorosette. ${ }^{49}$ Although a similar pattern for p53 and p21 staining was observed in some pseudorosettes in our tumours, such a strictly defined distribution of these two cell markers was not observed in all pseudorosettes and in all tumours. In the choroidal melanomas, p21 positivity decreased in tumours with a high percentage p53 expression. It would be expected from these results that, as a result of a decrease in the "arrest" function of p21, a positive correlation may exist between p53 expression and the MIB-1 growth fraction. Although such a correlation between p53 and proliferation markers has been observed in immunohistochemical investigations of other tumours, ${ }^{66-68}$ such a relation could not be demonstrated in this study. The only influence observable on the growth fraction of uveal melanomas was that of irradiation which resulted in a significant decrease in the MIB-1 growth fraction, as previously reported by other authors. ${ }^{69-71}$

Apart from its cell arrest inducing function, p53 is also involved in the induction of PCD; a direct correlation between p53 expression and apoptosis has been demonstrated in some tumours. ${ }^{34}$ Retinoblastoma cells were negative for BCL-2, the antidote to PCD; perivascular 
glial cells and scattered astrocytes within the tumour islands only were positive for BCL-2. This absence of BCL-2, together with the extensive apoptosis observed in the majority of the retinoblastomas, would tend to support the suggestion of Nork et al, that apoptosis in retinoblastoma is most likely p53 induced. ${ }^{49}$ Our findings, however, contrast with those of Yuge et al, who described weak positivity for BCL-2 in all retinoblastoma cells. ${ }^{57}$ The reasons for the discrepancy between results are not clear, although they are likely to be explained by the differing preparation of the slides before immunohistochemistry (hydrogen peroxide incubation; microwave antigen retrieval) as well as in the differing immunohistochemical techniques. ${ }^{57}$

Uveal melanoma cells, in contrast, were consistently positive for BCL-2, in agreement with previous results where BCL-2 positivity has been described in $100 \%{ }^{72}$ and $90 \%{ }^{73}$ of cases. BCL-2 is considered to have a specific role in the survival of melanocytes. ${ }^{74}$ Although a positive correlation between the oncogene $c$-myc and BCL-2 has been established in choroidal melanomas, ${ }^{73}$ there was no significant correlation between BCL-2 and any of the G1-S phase markers investigated in the present study. The interpretation of BCL-2 staining in uveal melanoma most likely requires the additional results of immunohistochemical staining patterns of other members of the BCL-2 family, such as BAX, which have to date been hampered by the unsuitability of available antibodies for formalin fixed paraffin embedded tissue sections.

In conclusion, retinoblastomas and uveal melanomas differ in their immunohistochemical pattern for cell cycle markers of the G1-S phase transition. Cyclin D1 protein expression is present in most uveal melanomas and absent in retinoblastomas, in agreement with the recently proposed autoregulatory feedback loop model proposed by Lukas and coworkers. $^{55}$ A positive correlation exists between cyclin D1 cell positivity and tumour cell type, location, growth fraction, and $\mathrm{pRB}$ positivity in uveal melanoma. The results presented are based on immunohistochemical investigations only and require molecular biological studies to underline their significance. The presence of cyclin D1 overexpression in choroidal melanoma suggests that other mechanisms at the molecular level, such as a possible translocation or heterogeneous promoter of the cyclin D1 gene, may be involved in their tumorigenesis. It also remains to be determined whether the expression of these G1-S phase transition proteins, particularly of cyclin D1 protein, has a role in determining tumour behaviour - for example, the onset of tumour metastasis.

The authors thank Mrs Helga Zimmerman-Höffken and Mrs Heidrun Protz for their superb technical assistance.

1 Sherr CJ. Mammalian G1 cyclins. Cell 1993;73:1059-65.

2 Dowdy SF, Hinds PW, Louie K, et al. Physical interaction of the retinoblastoma protein with human D cyclins. Cell 1993;73:499-511.
3 Ewen ME, Sluss HK, Sherr CJ, et al. Functional interactions of the retinoblastoma protein with mammalian D-type cyclins. Cell 1993;73:487-97.

4 Hinds PW, Mittnacht S, Dulic V, et al. Regulation of retinoblastoma protein functions by ectopic expression of human cyclins. Cell 1992;70:993-1006.

5 Motokura T, Bloom T, Kim HG, et al. A novel cyclin encoded by a bcl1-linked candidate oncogene [see comments]. Nature 1991;350:512-5.

6 Ott MM, Helbing A, Ott G, et al. bcl-1 rearrangement and cyclin D1 protein expression in mantle cell lymphoma. $f$ cyclin D1 protein expres
Pathol 1996;179:238-42.

7 Zukerberg LR, Benedict WF, Arnold A, et al. Expression of the retinoblastoma protein in low-grade B-cell lymphoma: relationship to cyclin D1. Blood 1996;88:268-76.

8 Bartkova J, Lukas J, Strauss M, et al. Cyclin D1 oncoprotein aberrantly accumulates in malignancies of diverse histogenesis. Oncogene 1995;10:775-8.

9 Bartkova J, Lukas J, Muller H, et al. Cyclin D1 protein expression and function in human breast cancer. Int $\mathrm{f}$ Cancer 1994;57:353-61.

10 Buckley MF, Sweeney KJ, Hamilton JA, et al. Expression and amplification of cyclin genes in human breast cancer. and amplification of cyclin

11 Kurzrock R, Ku S, Talpaz M. Abnormalities in the PRAD1 (CYCLIN D1/BCL-1) oncogene are frequent in cervical and vulvar squamous cell carcinoma cell lines. Cancer 1995;75:584-90.

12 Mate JL, Ariza A, Aracil C, et al. Cyclin D1 overexpression in non-small cell lung carcinoma: correlation with Ki67 labelling index and poor cytoplasmic differentiation. $\mathcal{F}$ Pathol 1996;180:395-9.

13 Michalides R, van Veelen N, Hart A, et al. Overexpression of cyclin D1 correlates with recurrence in a group of cyclin D1 correlates with recurrence in a group of forty-seven operable squamous cell carci

14 Naitoh H, Shibata J, Kawaguchi A, et al. Overexpression and localization of cyclin D1 mRNA and antigen in esophagea cancer. Am f Pathol 1995;146:1161-9.

15 Hirama T, Koeffler HP. Role of the cyclin-dependent kinase inhibitors in the development of cancer. Blood 1995;86: 841-54.

16 Hunter T, Pines J. Cyclins and cancer. Cell 1991;66:1071-4.

17 Hunter T, Pines J. Cyclins and cancer. II: Cyclin D and CDK inhibitors come of age [see comments]. Cell 1994;79: 573-82.

18 Herman JG, Merlo A, Mao L, et al. Inactivation of the CDKN2/p16/MTS1 gene is frequently associated with aberrant DNA methylation in all common human cancers. Cancer Res 1995;55:4525-30.

19 Ohta M, Berd D, Shimizu M, et al. Deletion mapping of chromosome region 9p21-p22 surrounding the CDKN2 locus in melanoma. Int $\mathcal{F}$ Cancer 1996;65:762-7.

20 Okamoto A, Demetrick DJ, Spillare EA, et al. Mutations and altered expression of p16INK4 in human cancer. Proc Natl Acad Sci USA 1994;91:11045-9.

21 Otterson GA, Khleif SN, Chen W, et al. CDKN2 gene silencing in lung cancer by DNA hypermethylation and
kinetics of p16INK4 protein induction by 5-aza 2'deoxycykinetics of p16INK4 protein inducti

22 el Deiry WS, Tokino T, Velculescu VE, et al. WAF1, a potential mediator of p 53 tumor suppression. Cell 1993;75: 817-25.

23 Michieli P, Chedid M, Lin D, et al. Induction of WAF1/CIP1 by a p53-independent pathway. Cancer Res 1994;54:3391-5.

24 Harper JW, Adami GR, Wei N, et al. The p21 Cdkinteracting protein $\mathrm{Cip} 1$ is a potent inhibitor of $\mathrm{G} 1$ cyclindependent kinases. Cell 1993;75:805-16.

25 Harper JW, Elledge SJ, Keyomarsi K, et al. Inhibition of cyclin-dependent kinases by p21. Mol Biol Cell 1995;6: cyclin-depend

26 Doglioni C, Pelosio P, Laurino L, et al. p21/WAF1/CIP1 expression in normal mucosa and in adenomas and adenocarcinomas of the colon: its relationship with differentiation. F Pathol 1996;179:248-53.

27 Shiohara M, el Deiry WS, Wada M, et al. Absence of WAF mutations in a variety of human malignancies. Blood 1994; 84:3781-4.

28 Gao X, Chen YQ, Wu N, et al. Somatic mutations of the WAF1/CIP1 gene in human prostate cancer. Oncogene 1995;11:1395-8.

29 Prokocimer M, Rotter V. Structure and function of p53 in normal cells and their aberrations in cancer cells:projection on the hematologic cell lineages. Blood 1994;84:2391-411.

30 Yunis JJ. Specific fine chromosomal defects in cancer: an Yunis JJ. Specific fine chromosomal defer

31 Piris MA, Villuendas R, Martinez JC, et al. p53 expression in non-Hodgkin's lymphomas: a marker of p53 inactivation? Leuk Lymphoma 1995;17:35-42

32 Haldar S, Negrini M, Monne M, et al. Down-regulation of bcl-2 by p53 in breast cancer cells. Cancer Res 1994;54 2095-7.

33 Silvestrini R, Veneroni S, Daidone MG, et al. The Bcl-2 protein: a prognostic indicator strongly related to p53 protein in lymph node-negative breast cancer patients. $\mathcal{f}$ Natl Cancer Inst 1994;86:499-504.

34 Basolo F, Pollina L, Fontanini G, et al. Apoptosis and proliferation in thyroid carcinoma: correlation with bcl-2 and eration in thyroid carcinoma: correlation with bcl-2

35 Kock E, Naeser P. Retinoblastoma in Sweden 1958-1971. A clinical and histopathological study. Acta Ophthalmol Copenh 1979;57:344-50. 
36 Mahoney MC, Burnett WS, Majerovics A, et al. The epidemiology of ophthalmic malignancies in New York State. Ophthalmology 1990;97:1143-7.

37 Pendergrass TW, Davis S. Incidence of retinoblastoma in the United States. Arch Ophthalmol 1980;98:1204-10.

38 Sanders BM, Draper GJ, Kingston JE. Retinoblastoma in Great Britain 1969-80: incidence, treatment, and survival. Brf Ophthalmol 1988;72:576-83.

39 Knudson AG Jr. The genetics of childhood cancer. Cancer 1975;35:1022-6.

40 Jensen OA. Malignant melanomas of the human uvea: 25-year follow-up of cases in Denmark, 1943-1952. Acta Ophthalmol Copenh 1982;60:161-82.

41 Horsman DE, Sroka H, Rootman J, et al. Monosomy 3 and isochromosome $8 \mathrm{q}$ in a uveal melanoma. Cancer Genet Cytogenet 1990;45:249-53.

42 Horsman DE, White VA. Cytogenetic analysis of uveal melanoma. Consistent occurrence of monosomy 3 and trisomy 8q. Cancer 1993;71:811-9.

43 Prescher G, Bornfeld N, Becher R. Nonrandom chromosomal abnormalities in primary uveal melanoma. If Nat Cancer Inst 1990;82:1765-9.

44 Prescher G, Bornfeld N, Horsthemke B, et al. Chromosomal aberrations defining uveal melanoma of poor prognosis [letter]. Lancet 1992;339:691-2.

45 Sisley K, Rennie IG, Cottam DW, et al. Cytogenetic findings in six posterior uveal melanomas:involvement of chromoin six posterior uve

46 Sisley K, Cottam DW, Rennie IG, et al Non-random abnormalities of chromosomes 3,6 , and 8 associated with posterior uveal melanoma. Genes Chromosomes Cancer 1992;5: rior uveal

47 Speicher MR, Prescher G, du Manoir S, et al. Chromosomal gains and losses in uveal melanomas detected by comparative genomic hybridization. Cancer Res 1994;54:3817-23.

48 McLean IW, Foster WD, Zimmerman LE, et al. Modifications of Callender's classification of uveal melanoma at the Armed Forces Institute of Pathology. Am $f$ Ophthalmol 1983;96:502-9

49 Nork TM, Poulsen GL, Millecchia LL, et al. p53 regulates apoptosis in human retinoblastoma. Arch Ophthalmol 1997;115:213-9.

50 Norton AJ, Jordan S, Yeomans P. Brief, high-temperature heat denaturation (pressure cooking): a simple and effective method of antigen retrieval for routinely processed tissues. F Pathol 1994;173:371-9.

51 Gerdes J, Lemke H, Baisch H, et al. Cell cycle analysis of a cell proliferation-associated human nuclear antigen defined by the mor
$1710-5$.

52 Cordell JL, Falini B, Erber WN, et al. Immunoenzymatic labeling of monoclonal antibodies using immune complexes of alkaline phosphatase and monoclonal antialkaline phosphatase (APAAP complexes). I Histochem Cytochem 1984;32:219-29.

53 Fuchs U, Kivela T, Summanen P, et al. An immunohistochemical and prognostic analysis of cytokeratin expression in malignant uveal melanoma. Am f Pathol 1992;141:169 81.

54 Bechrakis NE, Bornfeld N, Schüler A, et al. Clinicopathological features of retinoblastoma after primary chemoreduction. Arch Ophthalmol 1998;(in press).

55 Lukas J, Muller H, Bartkova J, et al. DNA tumor virus oncoproteins and retinoblastoma gene mutations share the ability to relieve the cell's requirement for cyclin D1 function in G1. F Cell Biol 1994;125:625-38.

56 Nork TM, Schwartz TL, Doshi HM, et al. Retinoblastoma Cell of origin. Arch Ophthalmol 1995;113:791-802.

57 Yuge K, Nakajima M, Uemura Y, et al. Immunohistochemical features of the human retina and retinoblastoma. Virchows Arch 1995;426:571-5.

58 Otterson GA, Kratzke RA, Coxon A, et al. Absence of p16INK4 protein is restricted to the subset of lung cancer pl6INK4 protein is restricted to the subset of lung cancer
lines that retains wildtype RB. Oncogene 1994;9:3375-8.

59 Yeager T, Stadler W, Belair C, et al. Increased p16 levels cor relate with $\mathrm{pRb}$ alterations in human urothelial cells. Cancer Res 1995;55:493-7.

60 Beltinger CP, White PS, Sulman EP, et al. No CDKN2 mutations in neuroblastomas. Cancer Res 1995:55:2053-5.

61 Sakaguchi $M$, Fujii Y, Hirabayashi $\mathrm{H}$, et al. Inversely correlated expression of $\mathrm{p} 16$ and $\mathrm{Rb}$ protein in non-small cell lung cancers: an immunohistochemical study. Int $\mathcal{f}$ Cancer 1996;65:442-5.

62 Tsuzuki T, Tsunoda S, Sakaki T, et al. Alterations of retinoblastoma, p53, p16(CDKN2), and p15 genes in human astrocytomas. Cancer 1996;78:287-93.

63 Janssen K, Kuntze J, Busse H, et al. p53 oncoprotein overexpression in choroidal melanoma. Mod Pathol 1996;9:26772 .

64 Tobal K, Warren W, Cooper CS, et al. Increased expression and mutation of p53 in choroidal melanoma. Br $\mathcal{F}$ Cancer 1992;66:900-4

65 Wynford Thomas D. P53 in tumour pathology: can we trust immunocytochemistry? [Editorial] [see comments]. $\mathcal{f}$ Pathol 1992;166:329-30.

66 Costa MJ, Walls J, Ames P, et al. Transformation in recurrent ovarian granulosa cell tumors:Ki67 (MIB-1) and p53 immunohistochemistry demonstrates a possible mo-
lecular basis for the poor histopathologic prediction of clinical behavior. Hum Pathol 1996;27:274-81.

67 Golusinski W, Olofsson J, Szmeja Z, et al. p53, PCNA and Ki67 in laryngeal cancer. Pol f Pathol 1996;47:175-82.

68 Nawa G, Ueda T, Mori S, et al. Prognostic significance of Ki67 (MIB1) proliferation index and p53 over-expression in chondrosarcomas. Int 7 Cancer 1996;69:86-91.

69 Char DH, Huhta K, Waldman F. DNA cell cycle studies in uveal melanoma. Am ₹ Ophthalmol 1989;107:65-72.

70 Mooy CM, de Jong PT, Van der Kwast TH, et al. Ki-67 immunostaining in uveal melanoma. The effect of preenucleation radiotherapy. Ophthalmology 1990;97:127580 .

71 Schilling H, Weng Sehu K, Lee WR. A histologic study (including DNA quantification and Ki-67 labeling index) in uveal melanomas after brachytherapy with ruthenium in uveal melanomas after brachytherapy with ruth

72 Jay V, Yi Q, Hunter WS, Zielenska M. Expression of bcl-2 in uveal malignant melanoma. Arch Pathol Lab Med 1996;120: 497-8.

73 Mooy CM, Luyten GP, de Jong PT, et al. Immunohistochemical and prognostic analysis of apoptosis and proliferation in uveal melanoma. Am f Pathol 1995;147:1097104.

74 Yang E, Korsmeyer SJ. Molecular thanatopsis:a discourse on the BCL2 family and cell death. Blood 1996;88:386401 . 